International Journal of Child, Youth and Family Studies (2012) 2 \& 3: 146-163

\title{
DIS[S]CURSE[IF] CHALLENGES: PROFESSIONAL CONVERSATIONS IN CHILD AND YOUTH CARE IN FLUID MODERNITY
}

\author{
Sibylle Artz \\ Keynote Speech for Child and Youth Care in Action III Conference: \\ Leading Conversations in Research, Practice and Policy, \\ April 28 to 30, 2011, University of Victoria.
}

Sibylle Artz, Ph.D. is a Professor in the School of Child and Youth Care, University of Victoria, P.O. Box 1700, STN CSC, Victoria B.C., Canada, V8W 2 Y2.

E-mail: sartz@uvic.ca

I have, as you can see, entitled my talk: Dis[s]curse[if] Challenges: Professional Conversations in Child and Youth Care in Fluid Modernity. I chose this title, in part, with a smile on my face. We have, in the last few years, in what we sometimes refer to as the child and youth care "academy", challenged ourselves to work with language forms that signal our knowledge of, and affection for, the history, the geneology, of the ideas that support our practices and also show that we can speak the vernacular. New turns of phrase, new ways of employing words that for many of us have had fixed meanings, now force us to meet these words again in different guises, and so create the need for a reacquaintance, for hearing and seeing again in a different way, what we thought we knew: 
International Journal of Child, Youth and Family Studies (2012) 2 \& 3: 146-163

Words move [and] music moves...

Words after speech, reach into the silence...

Words strain, crack and sometimes break, under the burden,

Under the tension, slip, slide, perish,

Decay with imprecision, will not stay in place,

Will not stay still. Shrieking voices

Scolding, mocking or merely chattering,

Always assail them...(Eliot, 1944, p. 19)

Our words, our discourses, our "formal and orderly and usually extended expression of thought on a subject" (the definition of discourse found in the ninth edition of Merriam-Webster's collegiate dictionary, 1991, p. 361), are sometimes a little less than orderly even if they are extended. But after all, the Latin root of discourse is discurrere, which means "to run about” (Merriam-Webster's free dictionary, 2011, http://www.merriam-webster.com/dictionary/discourse) - and indeed we sometimes do that, in our minds and with our words, so perhaps we can be forgiven for our occasionally laboured erudition, our sometimes obfuscating efforts to communicate.

...[when] wrestling with words and meanings

...the knowledge derives a pattern, and falsifies, For the pattern is new in every moment

And every moment is a new and shocking

Valuation of all we have been...(Eliot, 1944, p. 26)

Perhaps, that is why our discourses and their analyses are often so hard fought and never finally won and each idea is subject to scrutiny and every discussion never over. We seem to be caught up in a dialectical understanding, one that opposes thesis with antithesis in the hope that the tension of opposites will somehow create a new and improved synthesis, where one set of ideas, modernity for example, is knocked out of the park by another set of ideas, post-modernity for example, and for a time, hopefully the rest of our lifetimes, we have it right and can take charge and manage accordingly; until, of course, the new synthesis becomes the old thesis, once again about to be opposed by the antithesis, and so it goes.

But really, that's probably not how it works. Our struggles are not merely caught up in the tension of two well-defined opposites, and those aspects of our human experience that we have for so long treated as "hard" concepts and even as trait variables - concepts like race, ethnicity, class, social position, culture, gender, sexual identity, personal identity - these are not merely fixed points or parts of an additive description of 
International Journal of Child, Youth and Family Studies (2012) 2 \& 3: 146-163

self, other and world, but fluid and emergent patterns, open to reinterpretation, to being lived in multiple ways at the same time. So I remind us:

Knowledge derives a pattern, and falsifies, For the pattern is new in every moment And every moment is a new and shocking Valuation of all we have been...(Eliot, 1944, p. 26)

Let me give you an example: In one of my professional discursive worlds, the research world that focuses on trying to understand the use of aggression and violence and the engagement in crime of young people, the public discourse tells us that youth today are much tougher and more entrenched in violent crime than ever before, and more dangerous than they have ever been, and that girls, who are seen to be ever more problematic over time, are much harder to work with because they are so emotionally out of control and much meaner and more devious than boys.

This discourse of the badness of youth today is intimately connected to the current "tough on crime" political discourse pushed by neo-conservatives that tells us that because most behaviour, especially criminal behaviour, is not amenable to change (for that is the underlying theme of this discourse), the only way to deal with crime is to build more prisons, mete out stiffer sentences, and keep more people in jail for longer periods of time so that we, the good people, will be safe. This discourse is purposefully "running to and fro", pumping up fear with sophisticated sound bites that are strong on message and weak on facts (Pascal, 2010).

My professional conversations in this research realm have, over the last nearly 20 years, come back again and again to these points.

So here I am in the middle way, having had twenty years...

Trying to learn to use words, and every attempt

Is a wholly new start... a new beginning...(Eliot, 1994, pp. 30-31)

My beginning is typically empirical. I like to look at the data, and I like to look at numbers. To help us with looking at the numbers, I refer us to a pie chart that provides us with an overview of crime in Canada: 
Figure 1: 2006 Total Canadian Court Cases

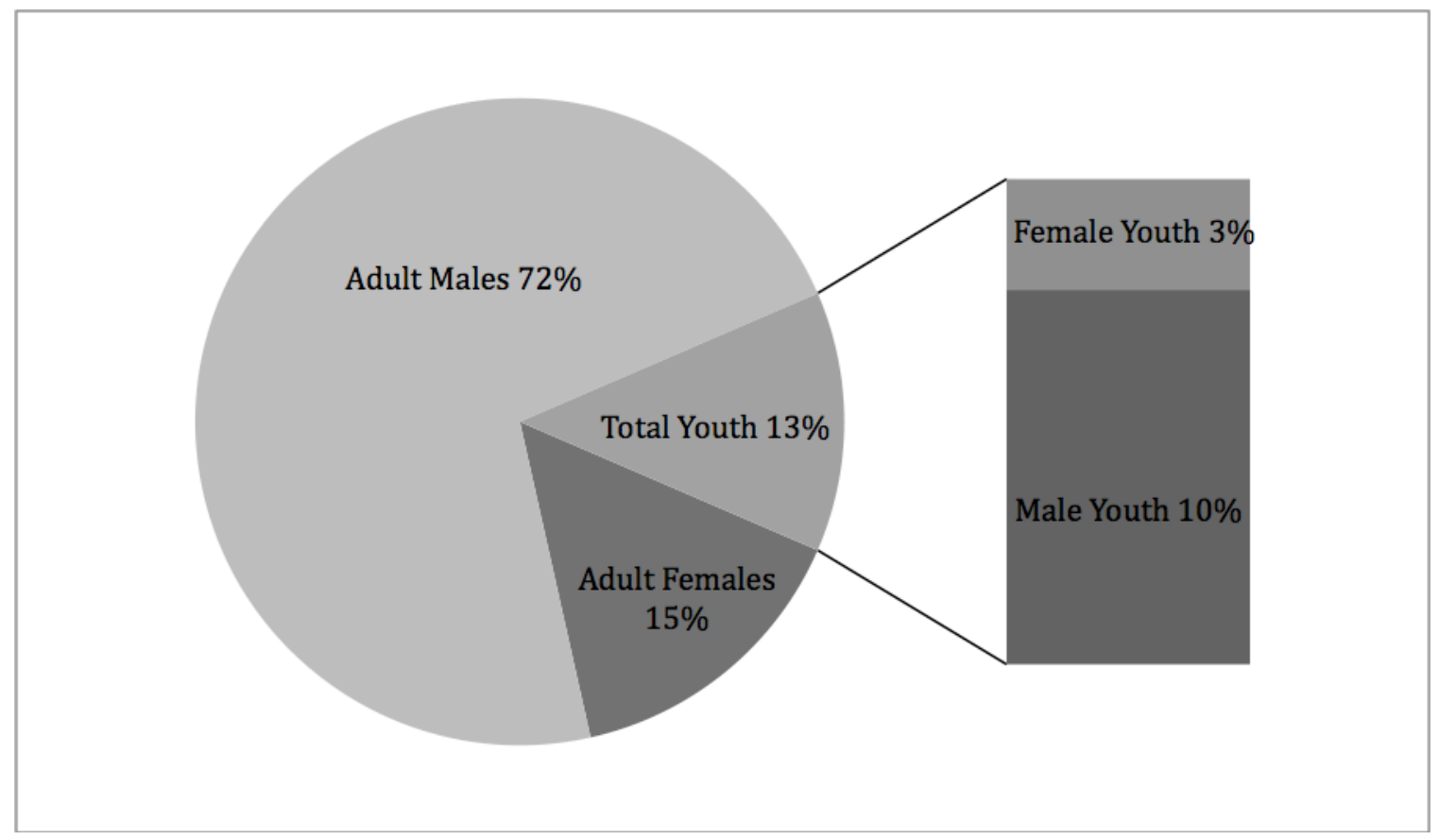

Statistics Canada, CANSIM Table 2520048 - Youth Court Survey, Number of cases, by sex of accused, annually \& 2520044, Adult Criminal Court Survey, Number of cases by sex of accused -2006

The overview of crime in Canada presented in Figure 1 has not substantively changed for the two decades during which I have looked at such charts and shows that only $13 \%$ of all Canadians charged and brought to court are minors, and of these only 3\% are girls (Statistics Canada, 2006a, 2006b, 2006c). It is not youth but adults, especially adult men, who are likely to enter the court system for crimes against persons, property, or the public order - the so-called index crimes which seem to always be our focus even though white-collar crime is far more prevalent than index crime and far more costly, but it's clean.

White-collar crime, defined by Edwin Sutherland (1949) as “a crime committed by a person of respectability and high social status in the course of his occupation” (p. 9), overlaps with corporate crime because the opportunity for fraud, bribery, insider trading, embezzlement, computer crime, copyright infringement, money laundering, identity theft, and forgery are more available to white-collar employees, and cost us literally "billions of dollars annually” (Henderson, 2001). But rather than focusing on major widespread issues like white-collar crime, the kind of crime that brought us a worldwide recession, we seem to be most pleased to devote front page stories and - as was, for example, the case in March of 2011 - assign three days worth of television and radio air time and newspaper space, including time as a top story on the national evening news, to a fight 
International Journal of Child, Youth and Family Studies (2012) 2 \& 3: 146-163

between two girls in the parking lot of a mall in Nanaimo.

Please don't misunderstand, I am not in any way suggesting that fighting and bullying are not serious issues. People are unquestionably harmed by these behaviours, but does this warrant sensational news coverage? In sensationalizing this behaviour are we not also making unacceptable social actions into actions worthy of celebrity? As we know, even bad publicity is better than no publicity and there's nothing like national television as an aid to building a rep. Let's take a look at how these kinds of things play out on a YouTube website entitled, Teenage Girls Fight, uploaded by CBC Television News on April 6, 2011. (Readers are encouraged to watch a news clip about this incident at the following YouTube web link: http://www.youtube.com/watch?v=nSBBsrn10OQ.)

As we can see as we follow the story as told through the news clip, the introduction sets up the behaviour that is on display as "not pretty and far from ladylike", where girls are "throwing punches and pulling hair" and engaging in "a severe case of bullying”. Then, as we watch, other dynamics also play a role and through the sound bites that are offered, the discourse is shaped in a very particular way.

First we notice that we can view the news clip as many times as we like for as long as this clip is posted on YouTube and each time we view the clip we again learn that the story is characterized as a "CBC TOPSTORY”. But if we look more closely we can also see that the material that is central to the story - the fight - consists of material that was pulled from a website called HATECLUBtva, which can be found at the following: http://www.youtube.com/user/HATECLUBtva

If we visit the HATECLUBtva site, we will learn that this is a Rap Hip Hop website where a bystander, not a journalist, posted the video of the fight as a backdrop for his rap song, a song in which the word "bitches" figures prominently, a video which was removed from the HATECLUB site at the behest of the police but now lives on as a "CBC TOPSTORY”. This top story might never have been a story at all if our opportunist songwriter and would-be video artist had not used the fight as a medium for his song and posted it on the web. It is, therefore, entirely possible that this fight would have gone unnoticed and these "unladylike" girls would never have come to our attention. But someone did notice the posting and the raw material that was first a music video is reshaped for the evening news and its ongoing perpetual life on the World Wide Web and has become a "serious offence".

That seriousness is certainly taken up by those who report and discuss the problem on the evening news, all of whom are sombre and concerned adults: a straightfaced reporter who reports the fight, a frustrated and worried mother who sees the event as evidence that “there's no rules and nobody cares about life anymore”, and a uniformed police officer who speaks to an investigation. Pain and loss are also expressed and this March 2011 fight between these girls is linked to the March 2010 tragic suicide of Ashkan Sultani, a student in the same school district. The school district is then highlighted as a central player in both events, the fight is characterized as criminal 
behaviour, and a known expert (also serious) is given eight seconds to speak to a possible intervention.

Positioned against the words of the serious adults are comments from youth that turn the event into gossip about clothes and hair and a prevalence-based description of the problem that youth don't try to stop, even though about the same number of students who report being affected by bullying state that they try to intervene. And there we have it, an example of some of the public discourse on girls and aggression. We also know now that after a month of investigation, assault charges were laid and the girls involved became crime statistics.

A further examination of crime statistics as, for example, those presented in Figure 2: Girls in Court by Charges as Compared to Boys and Adults - 2006, shows us again that young people, especially girls, including girls who fight in parking lots, and, for that matter boys, are the least of our problems.

Figure 2: Girls in Court by Charge as Compared to Boys and Adults - 2006

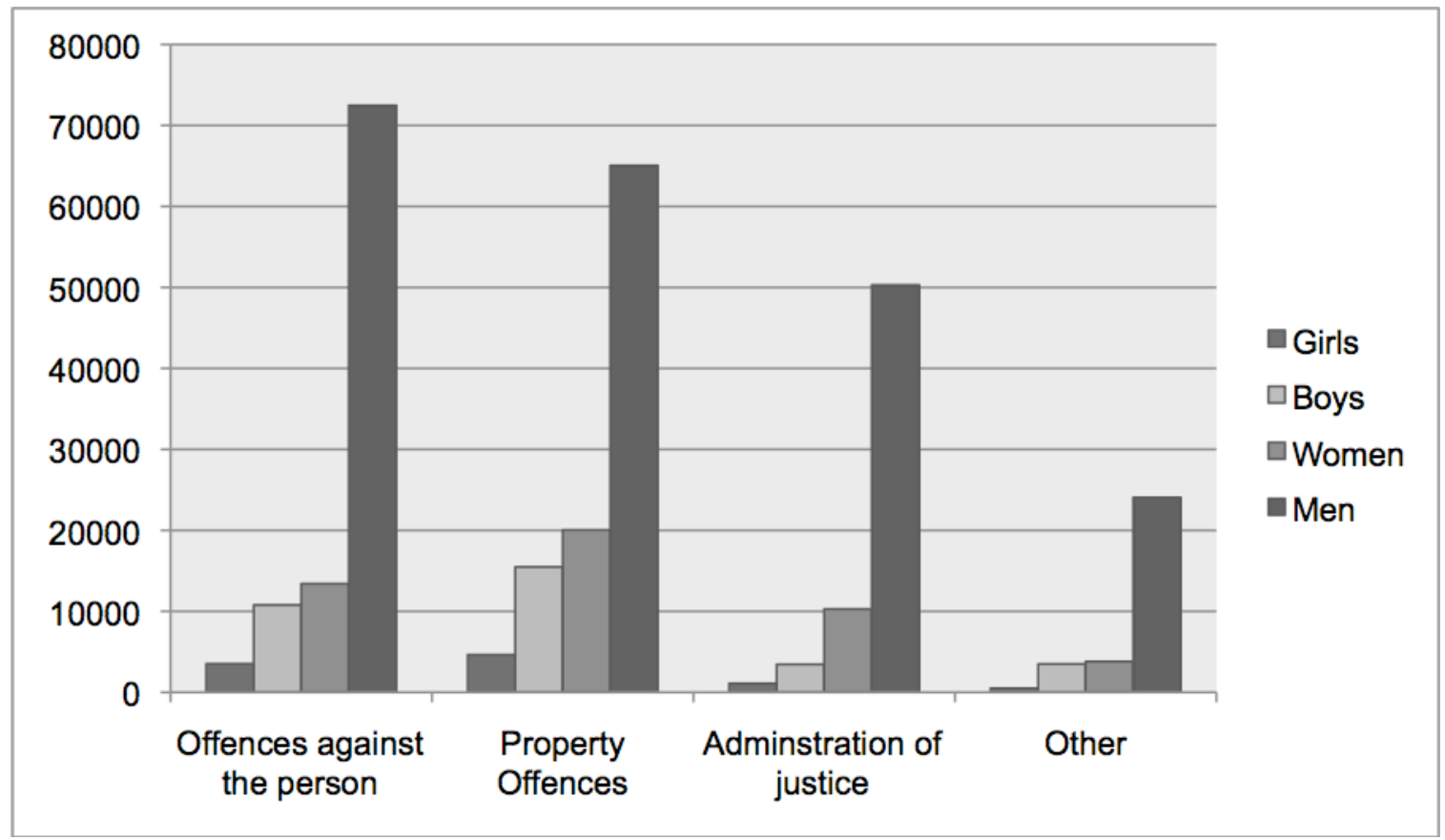

Statistics Canada, CANSIM Table 2520048 - Youth Court Survey, Number of cases, by sex of accused, annually \& 2520044, Adult Criminal Court Survey, Number of cases by sex of accused - 2006 
Still, in Canada, we seem to be particularly afraid of our "bad" kids. Until recently, Canada was known internationally to have one of the "harshest regimes for young offenders in the Western world” (Mallea, 1999, p. 3). International comparisons made in 1999 alerted us to the fact that Canada was creating more space to incarcerate youth than many other developed countries. On the assumption that the number of youth prisons that exist in a country is generally correlated with the number of youth serving time in custody, Figure 3: International Comparison of Youth Prison Facilities, 2000, serves to illustrate this point by comparing the number of youth prison facilities per 100,000 youth across six Western industrialized countries and shows that in 1999, Canada far outstripped its nearest competitors when it came to imprisoning young people 12 to 18 years of age.

Figure 3: International Comparison of Youth Prison Facilities - 2000

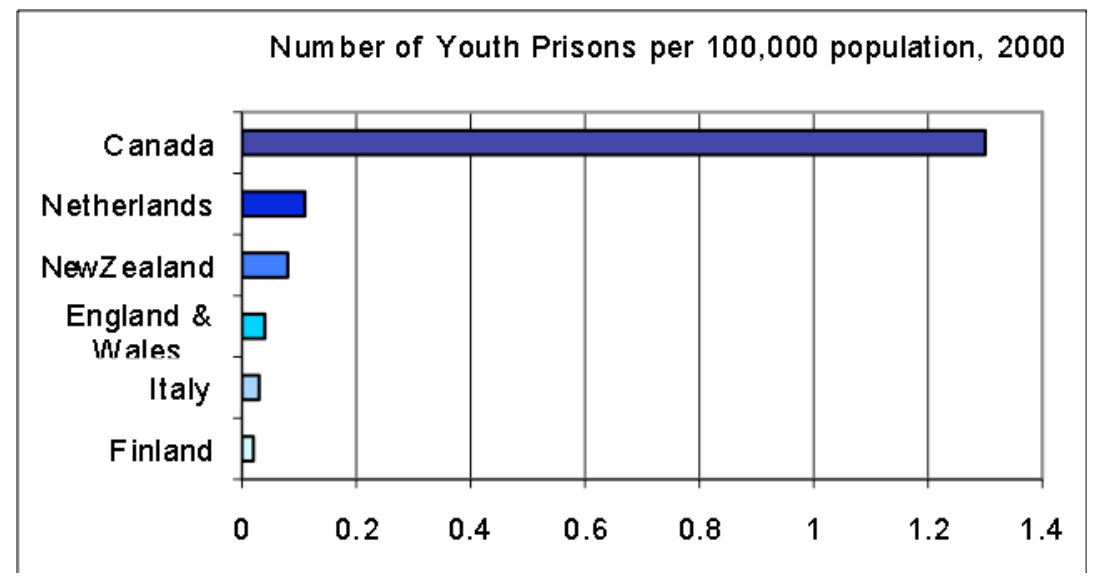

United Nations Office on Drugs and Crime, Centre for International Crime Prevention, 2001.

Our over-incarceration of young people has certainly been noted and we have, since 2003, replaced the Young Offenders Act, which was seen to be at the heart of our over-incarceration, with the Youth Criminal Justice Act (YCJA) and the number of youth sentenced to custody has decreased overall. As Figure 4: Proportion of Accused Youth Cleared by Means Other than Formal Charges after the YCJA shows, there has been an approximately $20 \%$ increase in the number of accused cleared by means other than formal charges across all major criminal code offence categories and that is good news. So, in 2006 , " $58 \%$ of accused youth were given a warning, caution, referral to a community or extrajudicial program or handled through some other means in lieu of formal charges” (Taylor-Butts \& Bressan, 2007, p. 4).

It is also worthy of note that since the introduction of the YCJA in 2003, decreases in charge rates have been greater for female youth $(-31 \%)$ when compared to 
their male counterparts (-25\%). But there is a rub: Although the Youth Criminal Justice Act was designed to deal with over-incarceration, it had an additional purpose - it was also a political reply to the characterization of the Young Offender's Act (YOA) as overly weak on crime.

\section{Figure 4: Proportion of Accused Youth Cleared by Means Other than Formal Charges after the YCJA}

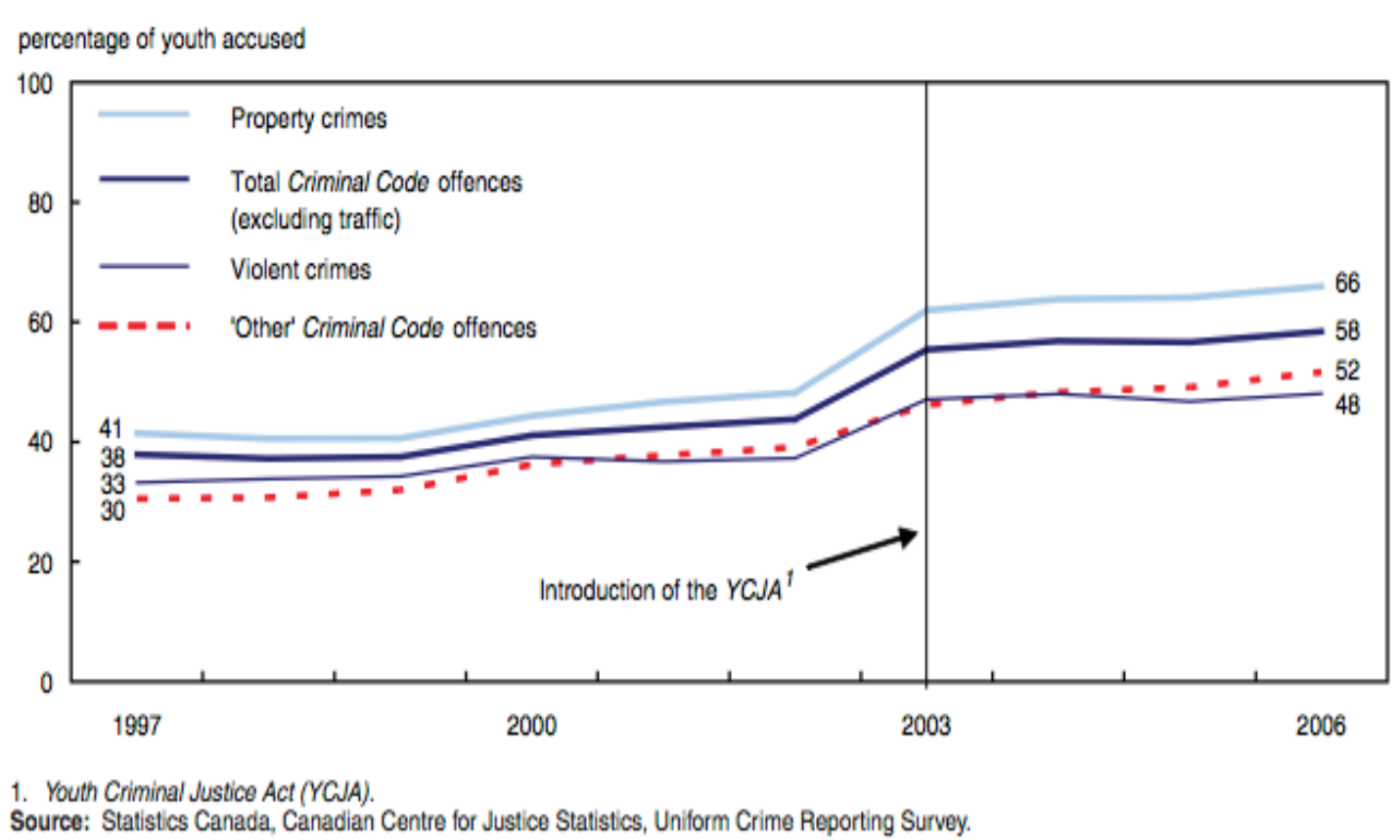

That led to the inclusion in the new act of a provision that lowered the presumption of an adult sentence to the age of 14 from the age of 16 and maintained the characterization of failure to comply with a non-custodial sentence as a serious offence http://www.justice.gc.ca/eng/pi/yj-ji/ycja-lsjpa/back-hist.html (The Youth Criminal Justice Act, 2009-09-04). This inclusion of failure to comply in the category of offences for which custody is an option, has left the door wide open to jailing young people for "breaching" their probation orders and has contributed to a substantial number of youth, especially youth from poor homes and communities with few resources, being jailed for non-serious offences. As Calvery, Cotter, and Halla (2010) tell us:

Despite the overall declines witnessed in admissions to youth correctional programs, trends in the use of remand are of note. Although the number of admissions to remand decreased in 2008/2009, admissions had grown in prior years and data indicate that, on any given day in 2008/2009, youth in remand outnumbered those in sentenced custody for the second year in a row. (p. 21) 
So while the number of youth sentenced to custody has declined, the number of youth, especially females, admitted to custody on remand (that is, staying in custody while awaiting trial) and the number of youth, especially females, being sent to custody for administrative offences (that is, breaches of bail or probation orders) has increased, particularly for Aboriginal females. This development highlights an ongoing problem for Youth Justice in Canada: Along with our not quite yet diminished penchant for overincarceration, we have an additional glaring issue that has a long history in Canada, namely the over-representation of Aboriginal people, particularly Aboriginal female youth, in custody as Figure 5: Over-representation of Aboriginal Youth Admitted to Correctional Services, illustrates:

\section{Figure 5: Over-representation of Aboriginal Youth Admitted to Correctional} Services

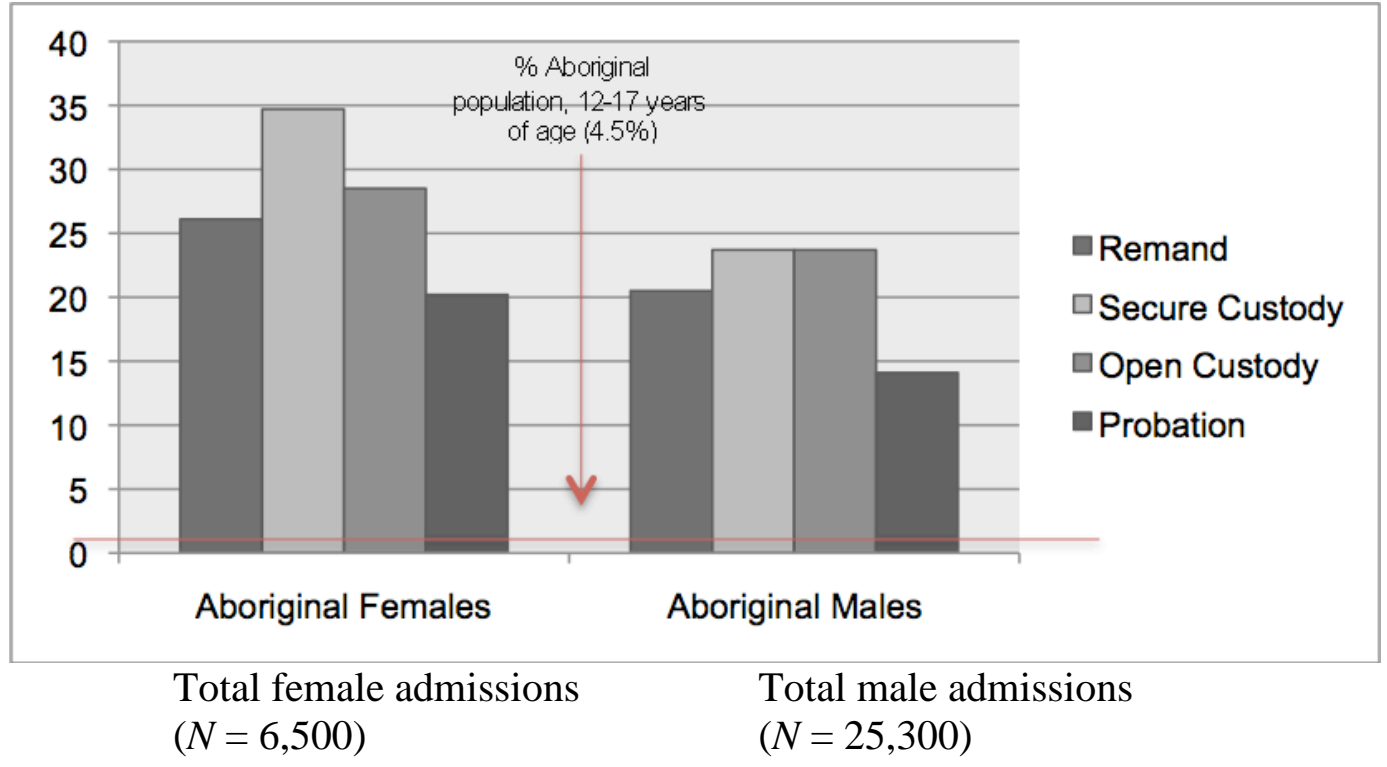

Statistics Canada, Canadian Centre for Justice Statistics, Youth Custody and Community Services Survey and Demography Division, Population Estimates, 2006 Census of Population.

Calvery, Cotter, and Halla (2010) also point out, in 2008/2009, in Canada, Aboriginal female youth represented $44 \%$ of all female youth sentenced to custody. They note that this is up from 29\% to 35\% in 2004/2005 and that, additionally, Aboriginal girls also make up $34 \%$ of females on remand and $31 \%$ of those admitted to probation. These researchers underline the importance of our taking note that these percentages for girls are all higher percentages than those for Aboriginal boys' correctional services involvement and are, of course, vastly disproportionate numbers given that Aboriginal youth aged 12 to 17 constitute $4.5 \%$ of the Canadian population. 
International Journal of Child, Youth and Family Studies (2012) 2 \& 3: 146-163

Currently in British Columbia, a province that takes pride in having one of the lowest youth incarceration rates in Canada, $58 \%$ of girls in B.C. custody centres are Aboriginal while only 8\% of the B.C. youth population is Aboriginal (Sharpe \& Gelsthorpe, 2009). Canada's youth justice practices seem to be especially problematic for Aboriginal girls who experience very high rates of remand and administrative charges. Information gathered by one official during one year at one B.C. custody centre helps to underline this point:

In the course of one year, 50 girls spent time in this centre for an average of 131 days each. Only six of these girls had committed a violent offence, the kind of offence meant for custody; however, 30 of the 50 girls were put in custody before they were even convicted of an offence. All 50 girls spent time in custody for a non-violent offence, a drug offence, or an administrative offence, crimes for which they could well have received an extra-judicial intervention. Further, 19 of the 50 girls were Aboriginal girls who were, once again, vastly over-represented at 38\% of the total group, and 17 girls were aged 13 or younger - children really - and five girls were pregnant or parenting. So while our official discourse, our Youth Criminal Justice Act, tells us that we should only jail young people for serious offences, other discourses also structure our actions (Personal communication, 2011, with an expert source working within the British Columbia youth custody system who wishes to remain anonymous). These findings beg the questions: Who are these girls and why are so many of them in jail?

We have known for some time that the young people we are locking up, sometimes but not very often for serious offences, are at risk for years before they commit any kind of offence because of the conditions in which they live. These young people live in what I call the "Fire Triangle" of family strife and violence, mental health challenges, and addictions. In February 2009, British Columbia’s Representative for Children and Youth and the Office of the Provincial Health Officer released a Joint Special Report entitled, Kids Crime and Care. Health and Well Being Of Children in Care: Youth Justice Experiences and Outcomes. This study, which is the largest of its kind undertaken in Canada, examines data on 50,551 children born in 1986 for a ten-year period beginning in 1997 and ending in 2007 and focuses on all members of this birth cohort who have had or have involvement with the youth justice system. The authors of this report state quite clearly that those who end up in the criminal justice system are:

a very vulnerable group of children and youth, many of whom are Aboriginal and in the care of the government. These children are often struggling to overcome significant issues and traumas such as neglect or abuse, and also frequently have mental health issues or developmental disabilities. Not surprisingly, being abused or neglected also nearly doubles a child's chance of having a youth justice record. Although the incidence of special needs and mental illness is high for children and youth in care or otherwise living out of the parental home, the statistics are even more alarming for those in care who are involved in the youth justice system. Of the youth in care involved with the youth justice system, almost 72 per cent have been reported with intensive behavioural problems or serious mental 
International Journal of Child, Youth and Family Studies (2012) 2 \& 3: 146-163

illness within the school system, compared with just over two per cent for the general youth study population. (p. 4)

Bernard Schissel (2010), in his article entitled, Ill Health and Discrimination: The Double Jeopardy for Youth in Punitive Justice Systems, tells a similar story. He states that, "ill health, both physical and emotional, not criminality is the defining characteristic of this vulnerable population" (p. 157) and backs up his statement with a careful analysis of the health outcomes and legal involvement of young offenders. His analysis, which once again points out that Aboriginal youth are vastly over-represented within the justice system and that our justice responses are highly racialized, also emphasizes the strong connection between justice system involvement, poor health, a lack of safety and security, and maltreatment and abuse, with girls in particular suffering from mental health challenges. It is indisputable, as Moretti, Odgers, Repucci, and Catherine (2011) point out, that decades of research confirm the connection between maltreatment and poor behavioural outcomes. They, like so many researchers before them, also found that for the girls who participated in their five-year longitudinal research project on gender and aggression, maltreatment is strongly linked to poor health and behavioural outcomes and that exposure to family violence, physical, emotional, and sexual abuse, and to neglect is strongly linked to criminal justice offending.

Research provides the evidence that allows us to unequivocally say that girls who become involved in the justice system are usually experiencing multiple forms of deprivation and abuse in their lives. We can also say with confidence that while these girls may be understood as offenders in the eyes of the law, they are usually victims first, long before they become perpetrators. In a study of a B.C. custody center, Corrado, Odgers, and Cohen (2000) found that the girls in that centre had multi-problem profiles:

All had histories of severe family dysfunction. In addition, $67 \%$ had been the victim of physical abuse at some point.... while $52 \%$...reported being a victim of sexual abuse...55\% report[ed] crack use, 49\% report[ed] heroin use and $65.7 \%$ indicat[ed] cocaine use. The average age of the onset of drug use was 12 years old. (p. 199)

A study conducted by the McCreary Centre Society (2001) noted even higher numbers for abuse: In that study 63\% of girls in the custody of the Province of British Columbia in 2001, the year in which the study was conducted, reported experiencing sexual abuse and fully $96 \%$ reported physical abuse. In a follow-up report conducted after the new Youth Criminal Justice Act became law, McCreary Centre Society (2005) researchers noted that little had changed with regard to the life worlds of the youth they surveyed in B.C.’s custody centres:

This report tells an extremely disturbing story. Many of the young people surveyed have survived physical or sexual abuse, and grew up in families where suicide, addiction and criminal activities were common. The majority has lived in government care at some time. Most have ongoing physical and mental health 
International Journal of Child, Youth and Family Studies (2012) 2 \& 3: 146-163

problems, and began using drugs and alcohol at an early age. Many of these young people are lonely and disconnected from their families and communities. Some have felt angry or hopeless enough to think about, or try, taking their own lives. (p. 5)

In that follow-up report, researchers found that among girls in custody, $92 \%$ reported a history of physical abuse and 63\% a history of sexual abuse, and once again $96 \%$ had a history of one or both.

Our odd response to these lives of deprivation, abuse, and maltreatment is that, in the absence of treatment facilities and access to therapeutic remedial and compensatory programs and interventions - those resources that regularly suffer death by a thousand small cuts - we are locking up our children and particularly our female Aboriginal children to keep them safe. As Amber Richelle Dean (2005) showed so evocatively in her study entitled, Locking Them Up to Keep them "Safe": Criminalized Girls in British Columbia, our youth justice system seems to be bereft of alternatives to incarceration and therefore has turned to carceral protectionism, that is the use of custody as a way to deal with non-criminal social problems. Dean cites the work of Corrado, Odgers, and Cohen (2001) who conducted a review of female young offenders' probation files and learned that $75 \%$ were locked up to keep them (not society) safe while only $4.5 \%$ were locked up to keep society safe. Dean cites the following example of the discourse of carceral protection found in a probation file by Corrado et al. (2001):

...Short of a custodial disposition, which is not desirable at this time, [I] am at a loss as to how to control or assist this defiant girl in the community.... Her history reflects a continuous cycle of refusal to cooperate with treatment attempts and running away.... It is my fear that this youth is in great danger of further victimization and self harm if not action is taken. (Dean, 2005, p. 15)

The language - the discourse - is telling: controlling defiance and the avoidance of further harm are paired and the solution is jail. A pedagogy of control is paired with a pedagogy of rescue and another girl lands up in custody.

The girl that is the subject of this discourse received a 45-day sentence for two administrative charges, two breaches - behaviours like not returning home on time and not attending school - for which jail is the answer. But what will she encounter in jail? She will encounter exactly what awaits our hair-pulling, punching, un-ladylike girls from Nanaimo who probably come from similar circumstances as those already described. Their first encounter with custody will be a strip search. Every time a young person is taken into custody, even if she has been taken from custody to court for a scheduled appearance and back again and has never been without constant surveillance, she will be strip-searched. That means that under the watchful eyes of a female custody officer she will be told to strip naked and her clothes, including her underwear will be set aside and packaged. Then she will be cavity searched for contraband, and after that, told to take a 
shower. Once showered, she will be issued with her prison clothing and assigned to her cell. And remember, many of these young women have been sexually abused, physically abused and maltreated, and have mental health challenges; some are disabled, some are developmentally delayed, all are humiliated, but this is for their own good.

While in jail, according to a survey conducted by the McCreary Centre Society (2001), 26\% of young women reported experiencing sexual comments or jokes, 22\% reported being touched or grabbed in a sexual way, $11 \%$ reported being punched, hit, or beaten up, and 45\% reported experiencing verbal abuse: So much for "their own good". Because boys always outnumber girls in custody, a girl in custody becomes an immediate target for sexual harassment and sexual abuse from boys whose models for power and control are premised on sexist stereotypical standards for behaviour so often learned from the highly abusive male models in their lives.

And yes, aside from encountering strip searches and further abuse, our young woman who breached her probation and our girl from Nanaimo, will get eight hours of bed rest (in a cell with no control of when she sleeps, awakes, has the light on or off, and what she is allowed to take into her cell) and three meals per day (with no choice about when and what she eats and how much), and while in custody, will attend school and do crafts and engage in physical activities (these if she behaves according to the rules). And some kids will say that jail was the best thing that ever happened to them and some will make their first ever positive relational connection to an adult in jail and will want to come back, because jail is better than the alternative (Artz, Blais, \& Nicholson, 2000). But just what does that tell us about the state of affairs of child welfare in our country?

The Youth Criminal Justice Act, our legal discourse on youth and crime, prescribes that our approach to youth crime should be based on "a more inclusive framework, focusing on public awareness, crime prevention, education, child welfare, health, family and the community” (Calverley, 2007, p. 2). But in order for us to do that,

substantial changes in social attitudes and structural inequalities are also urgently needed: Instead of investing significant economic resources into forcible means of protection or behavior change, we need to begin to directly address the circumstances that compromise girls' (and boys') safety (such as systemic racism, family poverty, community disintegration, eroding funding for schools and communities, child and youth maltreatment and sexual exploitation) and invest in voluntary programs and supports that facilitate girls' (and boys') development. (Dean, 2005, abstract)

Jennifer Charlesworth (2011), the executive director of the Federation of Community Social Services of British Columbia, stated on April 28, 2011, in an article in the Times Colonist that "Canada ranks a shameful 37th out of 38 among developed nations in spending on child care and early childhood development...32nd in the benefits it provides to families... [while] one out of six children in B.C. lives in poverty, one out of three arrives for their first day in kindergarten lagging behind their classmates 
International Journal of Child, Youth and Family Studies (2012) 2 \& 3: 146-163

developmentally" to say nothing of the fact that more than half of the children in B.C. who are in care are Aboriginal. These facts speak to our social organization, not to the failings of individual families because, as Dr. Charlesworth noted in her quote from Dennis Raphael, (a York University health policy professor and researcher): Government authorities and through them the electorate, we the people in other words, "shape children's living circumstances by influencing how income is distributed and [by] determining the availability of affordable housing and early childhood education and care... and governments shape parents' payment security and working conditions through legislation and regulation” (Victoria Times Colonist, April 28, 2011, p. A-13).

Those strip searches mentioned above and everything else to do with what leads to a girl or a boy ending up in jail are political processes as well as very personal ones. The choices involved are, at bottom, about politics and money. Bernard Schissel (2010) puts it very clearly: "The public policy and academic research that has centred...on the individual and his or her socio-cultural characteristics, while largely ignoring toxic contexts and structural inequalities is a political act with political and economic motivations” (p. 158).

The economic consequences of these political acts are enormous. Violent crime, much of which is preventable, is extremely costly: The cost of dealing with a murder is typically about $\$ 17.5$ million, a rape $\$ 448,532$, a robbery $\$ 335,733$, an aggravated assault $\$ 145,379$, and a burglary $\$ 41,288$ (DeLisi et al., 2010). These costs are staggering and cannot be ignored. Also not to be ignored is the finding that, despite declining crime rates, we have been subject to an increase in police budgets in Canada of $41 \%$ in the past 10 years (Morrow, 2011), even though we know that spending more and more on police, courts, and prison services does not reduce crime and victimization (National Working Group on Crime Prevention, 2007).

DeLisi and Vaughn (2011) tell us that, "Across an array of studies, the evidence for the value of prevention is compelling” (p. 3) and provide us with a long list of wellevaluated studies demonstrating that preventing violence and crime save inordinate amounts of public money, and public and private pain and suffering. DeLisi and Vaughn also tell us that for a youth at age 18, the benefits of preventing the costs of dropping out of high school, avoiding the costs of heavy drug use, and particularly avoiding the costs resulting to the individual and society from becoming a career criminal amount to a discounted present value of between \$2.6 million and \$5.3 million (U.S.). So why is there a constant call for tougher crime legislation instead of an ever-growing demand for crime prevention?

We know that crime prevention and intervention cannot merely be a matter of the management of individuals. When it comes to the commission of crime, systemic social and political processes that structure the marginalization of non-dominant groups have as much to answer for as many of the individuals who commit the crimes. We know this, but our knowledge seems, so far, to be unable to gain a foothold in policy and practice and “despite the rhetoric of Canada's youth justice system framework, there is a striking 
International Journal of Child, Youth and Family Studies (2012) 2 \& 3: 146-163

lack of funding for, or commitment to, alternatives to formal justice” (Schissel, 2010, p. 157).

So what do we do? I think that we have to recognize that all our work, our teaching, our research, and our practice is ethical work with moral consequences and, above all, it is political work with daily social consequences. Our current discourses on girls and crime need to be rewritten to accurately reflect how crime emerges. As practitioners and researchers we must revisit our units of analysis. As long as we distract ourselves with policy and practice discussions that foreground only analyses of individual differences, we will remain mired in wrong-headed notions of "every man for himself" where we all participate in a zero-sum game of winners and losers, and some - those children from the wrong side of life, for example - are made to be responsible for their own risk-embedded state and held accountable for the actions of a society that is quite willing to abandon them to their already pre-determined fate, because helping them might cost too much.

We live with a fear-based notion that we mustn't pamper those in need because they might take advantage, so we dole out stingy little bits of aid and make people wait their turn:

Victoria Women’s Transition House, wait 1 month; Aboriginal Mental Health, wait 3 months; Phoenix Human Services, wait 8 months; Children Who Witness Violence Program, wait 3 months; Beacon Community Services, wait 4 months (Victoria Times Colonist, April 8, 2011, p. A-14)

And when the wait is finally over, we offer services only to the most desperate and carefully ration for how long. The combination of caring prevention and intervention is our best option, our least expensive risk for a greater good, and one that, politically, we will have to invoke very soon because the alternative is bankrupting us morally and financially.

Thank you for giving me this opportunity to speak. Thank you also to Lorinda Stoneman, a Ph.D. student in the School of Child and Youth Care, for her invaluable assistance with the figures that appear in this document. 
International Journal of Child, Youth and Family Studies (2012) 2 \& 3: 146-163

\section{References}

Artz, S., Blais, M., \& Nicholson, D. (2000). Developing girls’ custody units.

Unpublished Report, Justice Canada.

British Columbia Representative for Children and Youth and the Office of the Provincial Health Officer. (2009, February). Kids, crime and care. Health and well being of children in care: Youth justice experiences and outcomes (Joint Special Report).

Victoria, BC: Authors. Retrieved from

http://www.rcybc.ca/Images/PDFs/Reports/Youth\%20Justice\%20Joint\%20Rpt\%2 OFINAL\%20.pdf

Calverley, D. (2007). Youth custody and community services in Canada, 2004/2005. Juristat, 27(2), Statistics Canada Catalogue No. 85-002. Ottawa: Statistics Canada.

Calverley, D., Cotter, A., \& Halla, E. (2010). Youth custody and community services in Canada, 2008/2009. Juristat, 30(1). Statistics Canada Catalogue No. 85-002-X. Ottawa: Statistics Canada.

CBC Television News. (2011, April 6). Teenage girls fight. Retrieved from http://www.youtube.com/watch?v=nSBBsrn10OQ

Charlesworth, J. (2011, April 28). When you vote, keep your children in mind: Know where parties stand on issues affecting Canada's youth. Victoria Times Colonist, p. A-13. Retrieved from http://www.timescolonist.com/life/When+vote+keep+children+mind/4688334/sto ry.html

Corrado, R., Odgers, C., \& Cohen, I. (2000). The incarceration of female young offenders: Protection for whom? Canadian Journal of Criminology, 42(2), 189207.

Corrado, R., Odgers, C., \& Cohen, I. (2001). The incarceration of female young offenders: Protection for whom? In T. Fleming, P. O’Reilly, \& B. Clark (Eds.), Youth injustice: Canadian perspectives (2nd ed., pp. 423-442). Toronto: Canadian Scholars Press Inc..

Dean, A. R. (2005). Locking them up to keep them "safe": Criminalized girls in British Columbia. A systemic advocacy project conducted for Justice for Girls. Vancouver, BC: Justice for Girls. Retrieved from www.justiceforgirls.org

Delisi, M., Kosloski, A., Sween, M., Hachmeister, E., Moore, M., \& Dury, A. (2010). Murder by numbers: Monetary costs imposed by a sample of homicide offenders. The Journal of Forensic Psychiatry \& Psychology, 21(4), 501-513. 
International Journal of Child, Youth and Family Studies (2012) 2 \& 3: 146-163

Delisi, M., \& Vaughn, M. G. (2011). The importance of neuropsychological deficits relating to self-control and temperament to the prevention of antisocial behavior. International Journal of Child, Youth and Family Studies, 2(1/2), 12-35.

Eliot, T. S. (1944). Four quartets. London: Faber and Faber.

HATECLUBtva: http://www.youtube.com/user/HATECLUBtva ${ }^{1}$

Henderson, L. (2001). Crimes of persuasion: Schemes, scams, frauds. Factors which allow the white collar crime problem to continue unabated.

Retrieved from http://www.crimes-of-persuasion.com/laws/problems.htm http://www.crimes-of-persuasion.com/author.htm

Mallea, P. (1999). Getting tough on kids: Young offenders and the "law and order" agenda. Winnipeg, MB: Canadian Centre for Policy Alternatives.

McCreary Centre Society. (2001). Time out: A profile of BC youth in custody. Vancouver, BC: Author. Retrieved from http://www.mcs.bc.ca/

McCreary Center Society. (2005). Time out II: A profile of BC youth in custody. Vancouver, BC: Author. Retrieved from http://www.mcs.bc.ca/pdf/time_out_2.pdf

Merriam-Webster's free dictionary. (2011). Springfield, MA: Author. http://www.merriam-webster.com/dictionary/discourse

Merriam-Webster's collegiate dictionary (9th ed.). (1991). Markham, ON: Thomas Allen \& Son Limited.

Moretti, M., Odgers, C., Reppuci, D., \& Catherine, N. (2011). Serious conduct problems among girls at risk: Translating research into intervention. International Journal of Child, Youth and Family Studies, 2(1/2), 142-161.

Morrow, A. (2011, January 7). What's the price of law and order? The Globe and Mail. Retrieved from http://www.theglobeandmail.com/news/national/whats-the-pricefor-law-and-order/article1862544/

National Working Group on Crime Prevention. (2007). Building a safer Canada. Institute for Crime Prevention, University of Ottawa, available online at: https://www.cacp.ca/media/coalitiongroups/efiles/5/BuildingaSaferCanada.pdf

\footnotetext{
${ }^{1}$ Since this keynote speech was given, the HATECLUBtva site has undergone some changes. If readers select the link provided here, they will find themselves instead at a video-sharing website where a number of fights between girls have been posted.
} 
International Journal of Child, Youth and Family Studies (2012) 2 \& 3: 146-163

Pascal, C. (2010, November 17). Harper tough on crime but soft on facts. Toronto Star. Retrieved from http://www.thestar.com/opinion/editorialopinion/article/891822-harper-tough-on-crime-but-soft-on-facts

Sharpe, G., \& Gelsthorpe, L. (2009). Engendering the agenda: Girls, young women and youth justice. Youth Justice, 9(3), 195-208.

Schissel, B. (2010). Ill health and discrimination: The double jeopardy for youth in punitive justice systems. International Journal of Child, Youth and Family Studies, 1(1/2), 157-178.

Statistics Canada. (2006a). Youth custody and community services. Canadian Centre for Justice Statistics, Survey and Demography Division (Population estimates, 2006 census of population). Ottawa: Author.

Statistics Canada. (2006b). Adult criminal court survey, number of cases by sex of accused (CANSIM Table 2520044). Ottawa: Author.

Statistics Canada. (2006c). Youth court survey, number of cases, by sex of accused, annually (CANSIM Table 2520048). Ottawa: Author.

Sutherland, E. H. (1949). White collar crime. New York: Dryden Press.

Taylor-Butts, A., \& Bressan, A. (2007). Youth crime in Canada, 2006. Juristat, 28(3). Statistics Canada Catalogue No. 85-002-XIE. Ottawa: Statistics Canada.

United Nations. (2001). Seventh United Nations survey of crime trends and operations of criminal justice systems, covering the period 1998-2000. Retrieved October 20, 2003 from http://www.unodc.org/pdf/crime/seventh_survey/7pv.pdf

Victoria Times Colonist. (2011, April 8). Letters to the editor. p. A-14.

Youth Criminal Justice Act: Summary and Background. (Date Modified: 2009-09-04). Retrieved from http://www.justice.gc.ca/eng/pi/yj-jj/ycja-lsjpa/back-hist.html 